\title{
Article
}

\section{Rewriting the future: Young people's stories of educational engagement}

\author{
Crook, Deborah
}

Available at http://clok.uclan.ac.uk/35152/

Crook, Deborah ORCID: 0000-0003-1852-1130 (2020) Rewriting the future: Young people's stories of educational engagement. Journal of the National Institute for Career Education and Counselling, 45 (1). pp. 59-67. ISSN 20461348

It is advisable to refer to the publisher's version if you intend to cite from the work. 10.20856/jnicec.4508

For more information about UCLan's research in this area go to http://www.uclan.ac.uk/researchgroups/ and search for < name of research Group>.

For information about Research generally at UCLan please go to http://www.uclan.ac.uk/research/

All outputs in CLoK are protected by Intellectual Property Rights law, including Copyright law. Copyright, IPR and Moral Rights for the works on this site are retained by the individual authors and/or other copyright owners. Terms and conditions for use of this material are defined in the policies page.

\section{CLoK}

Central Lancashire online Knowledge www.clok.uclan.ac.uk

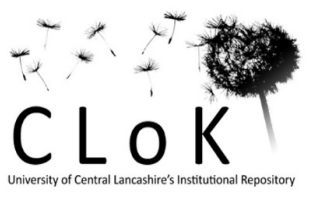




\section{National Institute for Career Education and Counselling}

October 2020, Issue 45

\section{GUIDELINES FOR CONTRIBUTORS}

Manuscripts are welcomed focusing on any form of scholarship that can be related to the NICEC Statement. This could include, but is not confined to, papers focused on policy, theory-building, professional ethics, values, reflexivity, innovative practice, management issues and/or empirical research. Articles for the journal should be accessible and stimulating to an interested and wide readership across all areas of career development work. Innovative, analytical and/or evaluative contributions from both experienced contributors and first-time writers are welcomed. Main articles should normally be 3,000 to 3,500 words in length and should be submitted to one of the co-editors by email. Articles longer than 3,500 words can also be accepted by agreement. Shorter papers, opinion pieces or letters are also welcomed for the occasional 'debate' section. Please contact the relevant issue co-editor(s) prior to submission to discuss the appropriateness of the proposed article and to receive a copy of the NICEC style guidelines. Final decisions on inclusion are made following full manuscript submission and a process of peer review.

\section{SUBSCRIPTION AND MEMBERSHIP}

The journal is published in partnership with the CDI twice a year and is available both in print and online (Print ISSN 2046-I 348; Online ISSN 2059-4879). Institutional subscription (online only) costs: $£ \mid 20$ (plus VAT where applicable). Annual print subscription costs $£ 30$ UK, $£ 35$ Europe outside UK or $£ 40$ outside Europe, including postage. Individual online subscription costs $£ 25$ (plus VAT where applicable).

Membership of NICEC is also available ( $£ 75$ pa or $£ 50$ pa for full-time students). Members receive the journal, free attendance at NICEC events and other benefits.

For information on journal subscription or membership, please contact:membership@nicec.org

\section{COPYRIGHT AND DISCLAIMER}

Articles are accepted on the condition that authors assign copyright or licence the publication rights in their articles to the National Institute for Career Education and Counselling (NICEC). An important goal of NICEC is to encourage freedom of expression. Individual viewpoints expressed in the journal do not represent NICEC as a whole.

\section{PUBLISHER}

The Journal of the National Institute for Career Education and Counselling is published in partnership with the CDI by: National Institute for Career Education and Counselling (NICEC), The Lodge, Cheerbrook Road,Willaston, Nantwich CW5 7EN.

\section{Contents}

\section{EDITORIAL}

2 Listening to new voices in the career development field

Anouk J. Albien, Bo Klindt Poulsen, Sanna Toiviainen, Miika Kekki, and Tristram Hooley

\section{ARTICLES}

6 Exploring processes of change in a life-design career development intervention in socioeconomically challenged youth

\section{Anouk J. Albien}

15 The last thing they need is career counselling! Critical reflections on interventions for the inclusion of marginalised people

\section{Jeanine van Halteren}

24 Understanding guidance counselling needs of adults with dyslexia through the lens of a critical-recognitive social justice perspective and a biopsychosocial model of disability

\section{Petra Elftorp and Lucy Hearne}

34 Are young people aged 16-19 using or expecting to use the gig economy for their careers?

\section{Esther Galfalvi, Tristram Hooley, and Siobhan Neary}

41 Parental career-specific behaviours and adolescent career adaptability

\section{Mara Šimunović, Iva Šverko, and Toni Babarović}

51 The relevance of Community Interaction Theory to 'Widening Participation': A role for the guidance practitioner as applied psychologist and sociologist?

\section{Emily Róisín Reid}

59 Rewriting the future: Young people's stories of educational engagement

\section{Deborah Crook}

68 Career counselling with life design in a collectivist cultural context: An action research study

\section{Aparna Bhalla and Gill Frigerio}

\section{NEWS}

77 Mary Munro

78 Call for papers | Forthcoming events 


\section{Listening to new voices in the career development field}

This issue of the NICEC journal presents the work of a number of 'early career researchers'. The term 'early career researcher' can be a difficult one in a field such as career development where relatively few people begin to research until they are already well into their own careers. Many of our authors have a history as practitioners of various kinds, which provides context and inspiration for their decision to begin to undertake research and publish. However, all of the lead contributors to this issue represent new voices that are beginning to shape the career development field through their research and writing.

By explicitly giving space to new voices in the field NICEC aims both to support the growth of the individuals participating in the issue and to showcase new ideas, theories and approaches. The current historical moment is characterised by technological change, political instability, global inequality and of course Covid-19. Everywhere we look our world is changing and the possibilities for career and for the provision of career education and guidance are changing with it. Because of this it is vital that we continue to search for new theories and listen to new voices in the field.

The editors for this issue came together through the European Doctoral Programme in Career Guidance and Counselling (ECADOC).We are Danish, English, Finnish and South African and sometimes resident in Norway and Switzerland as well as the above countries. The issue was therefore an exercise in international collaboration. It has its origins somewhere amidst summer school debates about career theory and research methods in the heat of the island of Malta during the 6th ECADOC summer school. But it developed further in Copenhagen at the Critical perspectives on agency and social justice in transition and career development conference organised by the Nordic Network on Transitions, Career and Guidance (NoRNet). As the editorial team was finalised we shifted from working at the periphery of European conferences and began to collaborate online. By the time the editing was beginning in earnest we were confined to our houses by Covid-19 and learning to work together through Zoom and other online tools.

We invited papers from new researchers in the field on any subject related to career development. We welcomed submissions from different research traditions (qualitative, quantitative, mixed-methods and conceptual) and invited contributors to explore career and career education and guidance across the life-course. We were overwhelmed by interest and were able to select the most interesting and high-quality submissions that we received. Submissions were selected based on any of the following criteria: I) the innovativeness of the research presented; 2) evidence of collaboration either at national or international level; and 3) whether the research addressed issues of diversity and inclusivity.

Before we introduce the articles in this issue, we will briefly provide some words about the ECADOC programme and the challenges of being an early career researcher in the field of career guidance and counselling.

\section{The European Doctoral Programme in Career Guidance and Counselling $\left(\right.$ ECADOC) ${ }^{1}$}

ECADOC brings together doctoral candidates working on career and career guidance from higher education institutions across Europe and beyond. This initiative embeds early career researchers in a supportive research community and encourages them to develop high quality and ethically sound career and guidance related research in Europe and across the world.

ECADOC was co-funded by the European Commission under the Lifelong Learning Programme from October 2013 to November 2016. The vision was to set up a sustainable European Doctoral Programme

I For more information on ECADOC please visit http://www. larios.fisppa.unipd.it/ecadoc/ 
specialising in career guidance and counselling research. ECADOC network members and alumni come from more than 30 European countries and beyond. The initiative is backed by all of the main organisations supporting career guidance research internationally including the Network for Innovation in Career Guidance and Counselling in Europe (NICE), the European Society for Vocational Designing and Career Counseling (ESVDC), the International Association of Educational and Vocational Guidance (IAEVG), the network of career counseling and guidance programs at higher education institution in the Nordic and Baltic countries (VALA), the Nordic network for Research on Transitions, Career and Guidance (NoRNet) and Euroguidance. These bodies and a range of national organisational and research groups help to recruit participants to the programme each year.

ECADOC's core activity is the organisation of an annual summer school that brings together researchers from across Europe and beyond.The summer school typically takes the form of a one-week doctoral course containing lectures, workshops and an innovative approach to mentored peer learning called 'collective academic supervision' (Nordentoft, Thomsen, \& Wichmann-Hansen, 2013). The summer schools include opportunities for $\mathrm{PhD}$ candidates to work with internationally renowned career guidance researchers, practitioners, and policy makers, as well as the editors of several journals. The summer school creates an opportunity for the organising committees to offer focused lectures on specific research themes, methods and ethics in career research in collaboration with the leading international scholars in the community. ECADOC has also offered a space where participants have been able to 'find each other' and connect around their mutual research themes and interests, resulting in fruitful discussions and joint international research projects.

Following the end of European Commission funding for ECADOC, the network of European higher education institutions engaged in the programme continued to organise the yearly ECADOC Doctoral summer school on a voluntary basis. Even Covid could not put a stop to the network with the organising team at Jönköping University in Sweden, led by Dr. Ingela BergmoPrvulovic, transforming the 2020 ECADOC summer school into an online event.Although researchers were unable to come together in Sweden, they were able to continue to exchange information and ideas and build a community between early stage researchers and more experienced scholars. This exchange and network building lies at the heart of ECADOC and all scholars are encouraged reach out to each other for collaboration, support and feedback in order to advance our field of research as a community of scholars. ECADOC 2021 will be hosted by Napier University in Edinburgh and led by NICEC's own Dr. Pete Robertson.

ECADOC has also facilitated and enabled participants to build other forms of collaboration. These include joint conference symposia such as the early stage researchers' symposia that have taken place at the International Association of Educational and Vocational Guidance conference, collaborative publications like the New perspectives on career counseling and guidance in Europe book (Cohen-Scali, Nota, \& Rossier, 2018) including Weber et al's (2018) development of a future research agenda for the field. This issue of the NICEC journal is the latest example of the kind of international, cross-disciplinary collaboration that ECADOC seeks to foster.

We encourage early career researchers to seek out information about ECADOC and how to participate in summer schools and be part of the international and diverse academic community. And we encourage experienced career researchers to actively look at the outcomes of ECADOC and engage in the discussion on the topics raised by early career researchers. We also encourage more established researchers to offer to host a future summer school.

\section{Early career researchers in the careers field}

Being an early career researcher comes with quite a few career-related issues. The working conditions for early career researchers are often characterised by precarious employment with few opportunities for advancement (Courtois, \& O'Keefe, 2015; Herschberg, Benschop, \& Van den Brink, 2018). This general problem is exacerbated for researchers working in a small, interdisciplinary field like careers where the number of fulltime and permanent academic roles is very limited.

Many careers researchers find themselves in broader academic groups like lifelong learning, education, work-life studies, sociology, or psychology with only a 
few colleagues who share their interest in career and career guidance. In this situation it can be hard to find people to talk to about your work and your research interests. The ECADOC network has sought to address this by forming an international community of like-minded individuals in the careers field. It provides participants with social and professional connections and solidarity and gives them close colleagues with the same academic preoccupation and theoretical field. These relationships endure beyond the immediate interaction of the summer school and lead to people becoming close colleagues, sparring partners, collaborators and constructive critics even when they live in different countries. This is a huge strength for the coming generation of career researchers that this network has been built already very early in their career.

ECADOC has shown that the number of doctoral students in the field is higher than ever and growing continuously. This is something that we celebrate as it contributes to a vibrant research culture and increases the capacity for research, evaluation, and the development of new theory. But, simultaneously, for those individuals pursuing a research career within the field it raises the question of how it is possible to create a successful career which enables them to make use of their skills and knowledge whilst also securing decent pay and conditions. For some this is about thinking about how they can forge a research career path outside of the traditional setting of universities and research institutions. In this sense, ECADOC can also be one potential networking platform to enable unconventional career steps or moves.

\section{About this issue}

As stated earlier, for this issue of the NICEC Journal we invited papers from new researchers on any subject related to career development. In the following section, we will give a short introduction and some insights into the articles making up this issue. They are presented in their order of appearance. They represent different research traditions, look into various phenomena and concepts within career development, and come from various geographical locations across the globe. The articles selected for publication reflect some of the most topical issues in the field: how career guidance could reach out to people in disadvantaged and marginal positions; how we could think through 'social justice lenses' in career guidance; how changes in the labour market structures could affect young people's entries to working life and how families, communities and broader cultural contexts come to frame the enactment of careers for different individuals.

In the first article, Anouk J.Albien takes on the important question of how career development interventions can lead to lasting changes. In her article, she explores how life-design career counselling supports change in a group of disadvantaged South African adolescents. Drawing on a qualitative postintervention evaluation of the adolescents' participation in the intervention, she shows how it elicited long-term changes in career development and facilitated reflective processes. She ends the article by discussing the implications of this for both research and practice.

Next, Jeanine van Halteren reflects critically on guidance interventions for the marginalised. She presents findings from her small-scale exploratory study into the lives and careers of survivors of contemporary slavery. Through the analyses of various data produced in the project, such as field notes, interviews and visual data van Halteren arrives at C.A.R.E. - connection, engagement, acknowledgment and respect - as key elements in delivering meaningful and context-sensitive support into the lives and careers of people considered 'marginal'.

In their article, Petra Elftorp and Lucy Hearne bring another 'marginal voice' to the discussion on careers and career interventions, focusing on experiences of adults with dyslexia. The authors draw from Axel Honneth's conceptions of recognition together with an interactionist and non-reductionist biopsychosocial (BPS) model of disability to examine adults' experiences on dyslexia from a social justice point of view. Elftorp and Hearne analyse experiences of misrecognition and transformative experiences of recognition and offer some valuable implications for both individual and collective career guidance practices.

\section{Esther Galfalvi, Tristram Hooley and Siobhan}

Neary explore whether young people use or expect to use the gig economy for their careers. The size of the so-called 'gig' economy, working mediated through online platforms such as Uber or Ebay, is increasing globally each year. Drawing on interviews with young people age 16-19, the authors discuss how young people in England perceive the gig economy 
and whether they feel that it will be relevant to their careers, with a view to discussing if the gig economy should be included in careers education programmes or guidance.

\section{Mara Šimunović, Iva Šverko, and Toni Babarović discuss how the recognition of parental career-specific behaviours as well as parents' understandings of the potential benefit of these behaviours could facilitate their children's career adaptability. Implications for special counselling interventions are provided for students who perceive that their parents are not providing enough career-related support. These address the gap that exists between parents and their children in understandings of the world-of-work.}

The next article comes from Emily Róisín Reid who originally wrote it in response to the NICEC Bill Law Memorial Award. In the article Emily looks at how Law's ( 198I) Community Interaction Theory helps to explain the career journeys of medical students from lower socio-economic backgrounds. She argues that Law's perspective remains relevant to the endeavour of widening participation to higher education and suggests that guidance practitioners have an important role to play as applied psychologists and sociologists.

Deborah Crook presents an example of rightsbased research in her article, where she addresses what kind of perspectives young people in northwest England have about enablers and barriers to continued education. She has applied participatory methods for young people to imagine steps towards future possible selves, including collaborative story-making with researchers. As an outcome, she questions models of aspiration-raising that prioritise particular trajectories, and emphasises the importance of inter-generational relationships, and especially the role and support of significant adults in the lives of young people.

The last article in this edition is an elaboration of a career counselling intervention within the Life Design paradigm applied in the collectivist cultural context of urban India. Aparna Bhalla and Gill

Frigerio provide a critical engagement with different career counselling methods and their theoretical underpinnings through an exploration of them with two clients. They use a step-by-step method to assess their usefulness in this collectivistic context and what implications these findings could have in facilitating the career transitions and trajectories for Indian clients, whose career needs are unique and culturally informed.

We hope that these articles provide proof of the ongoing innovativeness of our field. At the same time, we hope they will be a source of inspiration and offer an insight into the latest trends and ideas within career development research. Enjoy reading of these articles and listening to these new voices!

\section{Anouk J.Albien, Bo Klindt Poulsen, Sanna Toiviainen, Miika Kekki \& Tristram Hooley, Editors}

\section{References}

\author{
Cohen-Scali, V., Nota, L. and Rossier, J. (2018). New \\ perspectives on career counselling and guidance in Europe. \\ Springer: Cham.
}

Courtois, A. D. M., \& O'Keefe,T. (20I5). Precarity in the ivory cage: Neoliberalism and casualisation of work in the Irish higher education sector. Journal for Critical Education Policy Studies, I3(I), 43-66.

Herschberg, C., Benschop, Y., \& Van den Brink, $M$. (2018). Precarious postdocs:A comparative study on recruitment and selection of early-career researchers. Scandinavian Journal of Management, 34(4), 303-310. https://doi.org/10.1016/j.scaman.2018.10.001

Law, B. (198I). Community interaction: a 'mid-range' focus for theories of career development in young adults, British Journal of Guidance and Counselling, 9(2), |42-I58. https://doi.org// 0.| 080/03069888 I082582 I0

Nordentoft, H. M.,Thomsen, R., \& Wichmann-Hansen, G. (20I3). Collective academic supervision:A model for participation and learning in higher education. Higher Education, 65(5), 58I-593. https://doi.org//0.1007/ sl0734-0I2-9564-x

Weber, P. C., Katsarov, J., Cohen-Scali,V., Mulvey, R., Nota, L., Rossier, J., \& Thomsen, R. (2018). European research agenda for career guidance and counselling. In V. Cohen-Scali, L. Nota, \& J. Rossier. (Eds.) New perspectives on career counseling and guidance in Europe (pp. 219-250). Springer: Cham. 


\section{Rewriting the future: Young people's stories of educational engagement}

\section{Deborah Crook}

\begin{abstract}
Young people's educational trajectories are always provisional. This article considers young people's perspectives about enablers and barriers to continued education, and questions models of aspiration-raising that prioritise particular trajectories and are critical when young people cannot engage. Participatory methods enabled 30 young people aged 12-24 from disadvantaged areas in northwest England to imagine steps towards future possible selves. Through collaborative story-making with researchers, they established that inter-generational relationships are important to these journeys, especially support from adults who believed in their capabilities and encouraged young people's influence over decisions for change.
\end{abstract}

0000000000000000000

\section{Theoretical approach}

Collaborative story-making has been used as a participatory method to facilitate nuanced understandings of young people's lives through rigorous and faithful accounts of their experiences and participation in both data production and analysis (Satchwell, Larkins, Davidge, \& Carter, 2020). Young people can address issues of complex social relations involving values, meanings and beliefs, providing a reflective and practical means to develop solutions to problems, which scientific tests for 'truth' or limited logic fail to reveal (Hinyard \& Kreuter, 2007).

Such rights-based research can produce alternative narratives about young people's lives that emphasise less the need for young people to change or overcome adversity, and more adults' understandings of how to work with them for change. This repositioning of young people as experts in their own lives can be difficult for adults, especially when stories challenge childhood norms (Garrett, 2016; Shaw, 2012). However, Gair and Moloney (2013) suggest that creating and sharing insider stories to explore possible selves can be empowering and therapeutic.

According to Erikson (2007), possible selves theory considers future self conceptions as narratives, socially and culturally based in experience. How young people imagine their own futures is formed in relation to social contexts, including their schooling (Archer, DeWitt \& Wong, 20I4). How they remember experiences matters just as much as what they remember (Strahan \&Wilson, 2006). The act of reflecting on desirable and undesirable selves is itself an experience, potentially shaping identities, and motivating or moderating behaviours (Harrison, 2018; Destin \& Oyserman, 2009; Wainwright, Nee, \& Vrij, 20I8). Even with positive ideas about potential futures, young people may not take action if they perceive barriers will obstruct them (Destin \& Oyserman, 2009). How they perceive their influence over decisions is related to both their experiences and future imaginings.

Responding to a dearth of research in career education involving young people, the project presented here considered young people as agents for change (Archer et al., 20 I4; Erikson, 2007; Archer, 2007). It focused on the process of imagining futures (rather than the outcomes themselves) and the identification of resources young people perceived as necessary to their continued educational engagement. The article provides insight into what is involved in rewriting the future - the who, what, where, when and why. It discusses two specific themes that emerged through young people's collaborative story-making - 
their emphasis on inter-generational relationships and the role adults play in supporting their own decisionmaking.

\section{Context of study}

The UK has expansive achievement gaps between advantaged and disadvantaged students, especially in secondary education and in the north west of England where gaps continue to widen (Hutchinson, Bonneti, Crenna-Jennings \& Akhal, 2019). There are areas of high socio-economic disadvantage where, although young people attain benchmarks for educational achievement, few continue to higher education (HE). The National Collaborative Outreach Programme was set up to achieve the UK government's aim to double the proportion of young people from disadvantaged backgrounds in HE by 2020 through education, business and community collaborations, including FutureU who commissioned the present research.

The lack of educational progression has been blamed on a lack of aspiration associated with levels of deprivation (Whitty, Hayton \& Tang, 20I5). There is little evidence to support this, despite education policy being formulated on this premise (Archer, 2007; Archer et al., 20 I4; Hayward \& Williams, 20 I I); such supposition may itself present barriers diverting attention from structural forces (Harrison, 2018; Hayward \& Williams, 20I I). Increasing numbers attending $\mathrm{HE}$ has not countered the disproportionate selection of privately educated students from higher income families, thus Hayward and Williams (20II) suggest interventions should pay better attention to opportunity structures.

Neoliberalism has produced a global education reform movement that prioritises economic growth through standardisation, whereby particular career pathways are promoted as success (Archer, 2007; Archer et al., 2014; Grant, 2017;Wrigley, 2015). Whitty et al. (2015) suggests that young people from disadvantaged backgrounds possess habits, skills and dispositions less valued and embodied in HE. They may be considered failing or at odds with school systems, lacking aspiration, responsible for their own underachievement and expected to 'correct' perceived deficits (Harrison, 2018; Garrett, 2016; Archer, 2007). Simultaneously, Anglo-Saxon model welfare systems accept high levels of deprivation, lack universal services, and intervene only when considered dangerous not to do so, which places additional socioeconomic pressures on young people, often in tension with their rights (Spratt, 2016). These conditions compound criticism of young people's aspirations (Grant, 2017; Pimlott-Wilson, 20I I).

Limited concepts of aspiration as career pathway, rather than young people's own hopes and dreams, life satisfaction and equality, are contested (Harrison, 2018; Spohrer, 2016). Even so, policy and practice tend to support interventions as mechanistic means of attaining, rather than imagining and creating positive futures (St Clair \& Benjamin, 201 I; Hayward \& Williams, 20I I). Emphasis on academic qualifications and entry into HE at age 18, presents barriers for young people who have, for many reasons, been unable to thrive in education. Career interventions may ask young people to set goals, but rarely draw attention to barriers that must be overcome to achieve these goals, and rarely include imagining their futures whilst drawing on limited social resources within constrained contexts (St Clair \& Benjamin, 2010). Specifically, 'resolute goal-directed hope' (Grant, 2017, p297) does not work because disadvantaged young people are expected to change their dispositions or cultural habits, which reinforces the idea that it is personal deficit rather than social structures that constitute barriers. Such measures also fail to take account of the roles that adults play in fostering expectations (Goyette, 2008; Shaw, 2012).

All young people have participation rights, these include the right to a view in all matters that affect them, to information, and to education that enables them to reach their fullest potential. These rights are protected by the United Nations Convention on the Rights of the Child, 1989 (UNCRC), and ratified by the UK in December 1991, with obligations coming in to force in 1992. Career education research that acknowledges young people as holders of rights or their potential to contribute to career education development is scarce. Bassot, Barnes and Chant (2014) exceptionally suggest young people should be at the centre of career development design, delivery and evaluation. The UK has not addressed the criticism by the UN of the failure to ensure participation rights (CRC, 2008, pl5). One reason 
for this resistance is that enduring attitudes to childhood position young people as future citizens, producing a state of reinforced dependency and staged socialisation through schools, until they achieve adult 'completeness' (Prout \& James, 2015). This positioning draws attention away from young people's current lives and expectations. Rights-based research instead recognises how young people might contribute to shaping spaces that enable them to flourish.

\section{Research design}

This article introduces the project 'Rewriting the Future' (RtF) which aimed to explore young people's stories and their perceived enablers and barriers to continued educational engagement through participatory research using arts-based approaches. Thereby, young people are enabled to share experiences using more than words, responding to each individual's preferred communication style.Young people can steer the process, sharing what they want to say - the researcher working with rather than on or for young people (Aldridge, 2017). They can create characters with whom they and others can strongly identify, making immersive stories with potential to influence broad audiences (Hinyard \& Kreuter, 2007). The methods used in RtF were originally developed through Stories2Connect ${ }^{1}$, where writers and artists worked with young people to make stories about overcoming adversity, recognising that 'Experience, understood narratively, has both artistic and aesthetic dimensions' (Clandinin \& Huber, 2002, p. 162). In RtF, the design also drew on possible selves theory by encouraging young people to look at their educational journeys, whilst challenging straight line assumptions about achievement by using real life experiences to understand what planning for the future entails.

Drawing on my own experiences as a designer and teacher, I developed a movie-based theme to enable participants to create collective stories about their educational journeys and what they believed worked to help them achieve their hopes and dreams.

Arts-based participatory activities, such as drawing, songwriting and map-making, allowed young people to

I Further details for the project led by Professor Candice Satchwell and examples of data, including from this study 'Rewriting the Future,' can be found at http://stories2connect.org/ create movie plots to analyse and communicate their ideas, which the findings discuss.

Thirty young people aged 12 to 24 were recruited through three settings: I) Three males and six females (aged 12-15) attending children and family wellbeing services (CFWS); 2) nine males and four females (aged 16-24) who had experienced not being in education, employment or training attending a college access to education programme; and 3) three males and five females (aged 13-15) attending a voluntary sector youth club. They experienced disadvantage through complex combinations of poverty, family breakdown, bereavement, disability, violence, bullying, mental illness, exclusion from school, being a young parent, and being looked after by the state.

Informed consent was established from all participants, and parents/carers for those under 16, with procedures approved by university ethics committee. Ethical research with young people is complex, especially where there is potential that adverse experiences may be shared. This was countered with responsive approaches enabling the young people themselves to suggest ways of creating and sharing their stories, workers who knew them available for support if required, and the freedom to withdraw at any point (Skånfors, 2009).

\section{Data collection and analysis}

Participatory workshops were designed and facilitated by two researchers (including the author) at all three settings. There were between six and twelve hours contact time at each setting. Young people were invited to draw or describe themselves and talk about their experiences of education and their hopes and dreams. Some created movie characters; the youth club group animated these with a filmmaker. All three groups co-produced maps about important places in their lives. The researchers facilitated these activities using questions, visual prompts and providing resources and flexibility with the planned activities. For example, young people in the CFWS took the researchers on a walk around their town and this was filmed when we asked them what it is like living and studying in their town. The college group additionally drew storylines to share their educational journeys and what returning to college meant to them. 
Alongside the workshops, individual semi-structured interviews, lasting between 15 and 65 minutes, were audio recorded and transcribed.

Data included: audio and video recordings and transcripts; drawings; ideas for movies and songs; and maps. After each workshop, the researchers logged notes in a reflective journal of encounters that were not always apparent in these materials. For example, what young people responded to and were predominantly concerned with, as well as how they related to each other and the adults present. Analysis was an ongoing, responsive and collaborative process between the two researchers and young people (Satchwell et al., 2020). This involved a discussion at each workshop to check for meanings of recordings or interpretations of materials produced.

Models of participatory research can position participants as subjects, actors, or leaders, often shifting between these roles. The researchers attempted to achieve a balance between the time needed to build trust and enable young people to influence what and how they shared their stories, but also what was realistically achievable using the resources available (Aldridge, 2017). A commitment to young people's influence meant accepting their versions of experience, but this was also limited by the researchers' interpretations. We encouraged young people to identify key messages that they believed were crucial for realisable change through their movie designs. In doing so, we purposefully drew attention to the subjectivity involved in knowledge creation.

\section{Findings}

All the young people shared talents and interests and talked about achievements in their lives, as well as potential careers, which challenged assumptions about low aspirations (St Clair \& Benjamin, 20I I). Some hoped to shape careers around their talents and interests, such as art, writing or music. Most talked about relationships and having their own families; with one young parent expressing how he hoped he could become a good dad. They described places they hoped to visit or live. They also described complex situations including being homeless (sofa surfing), difficult relationships with family, experiencing bullying and violence, and poor mental health.
Emerging themes about educational engagement were expressed through contexts of family, place, school, finances, information and social networks resonating with Archer et al. (20I4). Interconnecting were themes about significant adults, consistency, knowledge, social life and personal qualities. These could be barriers or potential enablers of young people's educational engagement in the different contexts. During analysis, young people identified how important intergenerational relationships were in constructing these barriers and enablers, and how they believed these are potentially a key to change. Their co-created movie designs helped to summarise these perspectives and are shared in the next two sections supported by extracts from their interviews and discussions.

\section{Inter-generational relationships}

The youth club cohort co-created a movie design based around the image of an onion that focused on inter-generational relationships. As each layer peeled away, it revealed more about their lives. The data are from their discussions and interviews, with some of the single words from their maps. The onion skin was their hometown, which appeared a pleasant 'leafy suburbia'. In the next layer they wanted to show a different reality, using words such as 'scummy, 'judging,' 'unaccepting,' 'a place I want to leave,' knife crime,' 'drunken addicts,' 'underage smoking,' 'false news' and 'no love.' Next they introduced tensions around these perspectives:

'This place where I exist is where I live, get my education, meet my friends, and figure out who I am. What happens here matters.'

'But just because one person does something does not mean we all do the same.We are all different.'

In the next layer, they identified safety zones, safe spaces to meet new people, friends and be sociable:

'Home and school are where we have to be most of the time...If things aren't ok then we really lack anywhere to go.'

'What we have discovered though is that some things make a difference. It's not just places that count but people and how they are with us.' 
They then wanted adults to know and take on board that their hopes and dreams are not just about making money and passing exams. They produced a list of what they wanted from life:

- to be able to explore the world

- to make friends and have families

- our communities to be safe places

- schools to work with us on what we can do, not what we can't

- adults to listen to us and see us for who we really are

Their conclusions at the onion's centre were:

'It can take a real effort to be who we want to be but all of us are capable of achieving our hopes and dreams. We need space to think and speak to work this out.'

Tense inter-generational relationships were described by all three cohorts. It is important to understand the depths of injustice many of these young people felt in order to appreciate the differences they identified when mentioning significant adults (described in the next section) who they claimed were exceptions.

Availability of local resources also influenced how they thought young people in general were valued, with the CFWS group describing fear to venture out because of potentially violent crime. At the same time, they felt locked in due to parents' worries and because the public transport infrastructure was poor. Their video of the walk around the area focused on deserted public spaces including playgrounds. The youth zone, where their workshops were held, was only open to people attending CFWS for interventions, so they felt they had nowhere to go. In contrast, young people at the voluntary sector youth club, met regularly and had started their own interest group. Even so, they described tensions in the town about how the youth club was perceived and how some young people would not attend because it was so tightly structured and controlled.

For most of the participants, school was a difficult environment characterised by the following reasons: constantly changing classes and teachers; bullying; and the perception that adults did not care or spend time to get to know them. Young people in the college described how if they did not complete their course, they could never again access education. Many felt let down after experiencing bullying or isolation related to disabilities or poor mental health at school. All they wanted is what they considered to be their real stories to be recognised, rather than those created by the adults around them:

'The CAMHS worker support workers comes to my home so my mum makes it look like we're absolutely fine at the home but we're not...'

Adult belief in, or expectations of, individuals was significant, which resonates with Goyette (2008) and Shaw (2012). For example, young people attending CFWS described how, because they were not in the 'top sets' for their subjects, teachers did not talk about HE or involve them in visits. In contrast, a young woman with special educational needs, whose family had high expectations of her, had recommended she attend the college access course to move forward:

'They want me to do good in life basically, so they're going to support me... and similar to my friends they always ring me, they always text me, and they check up on me, all the time basically.'

\section{Recognising and supporting young people's capacities for change}

Inter-generational relationships were also recognised as important for enabling change, especially in education, resonating with Bessell (2017) and Shaw (2012). Young people described times when they felt successful and had been supported. Whether parents or carers, other relatives, leaders or teachers had been supportive, these significant adults' inspired them through consistent listening, giving advice without judgment and genuinely believing in their capabilities to shape their own lives. These relationships made the difference between whether they engaged in or attended school or college and coped with detrimental situations and instability within the systems. This finding is consistent with McNamara, Harvey and Andrewartha (2017) and Sanders, Munford and Thimasarn-Anwar (2016). One academically able young woman with ASD, described a significant teacher as: 
'He always had faith in me, and always helped with things that have needed to be answered. I have always been included with conversations with him and he's just really funny and witty.'

Recognition of a young person's personal qualities, consistently communicating high expectations, not judging, and the timely sharing of knowledge, were characteristics important in whether a young person took on board the information offered by adults:

'Originally I didn't actually want to go to university, because, oh there's no point in that I want to become an author. I don't need a degree to become an author...my mum said ... you are going to university, because you have that opportunity, so you might as well take it, because there are so many other people who don't have that opportunity, so now this is your responsibility to take it ... I magically managed to get into set one for Maths this year, and my mum said see you can do it, you are capable, so now you need to work for it and earn your place there.'

A second movie design produced at the CFWS highlighted tensions young people had identified between their hopes and dreams, and how they were treated in school and their community.

The plot is summarised here:

There is a boy called Bill who lives in [town] and he is being bullied. The reality is dull, people such as bullies and teachers put barriers in Bill's way, saying he can't do it and putting down his confidence. He was given a hat from a family member. When he wears this hat, he is transported to the farm world where he is on the farm with the unicorns and the flying pigs. It is like a dream life. When he is worried, he likes to put on his favourite song too. When Bill is in a horse race, he falls off a lot, but he keeps getting back on. It doesn't matter where he finishes, just that he eventually does.

The boy who did most of this design described two significant family members: one who actively encouraged him to get fit; and the other to pursue his dreams of working in the film industry through his artistic talents. Through their consistent encouragement, following years of anxiousness about his body, severe attacks by bullies, and perceived lack of support for change at school, he had identified his own personal qualities - perseverance and willingness to try even if he did not always succeed. By then collaborating with these significant adults, who consistently communicated higher expectations, he realised he could change his story.

\section{Conclusions}

Educational trajectories shift when opportunities, experiences and expectations shift. Wainwright, Nee and Vrij (2018) suggest that the most impact occurs if young people can develop strategies for achieving these shifts. This research offers a potential way forward by suggesting educationalists make space for young people to simultaneously think about and work out how they might achieve possible future selves and access the resources needed to continue their journeys. By working with researchers to analyse data about their own perspectives, young people suggested that inter-generational relationships influence whether particular themes become barriers or enablers to these journeys and that these may also be a key to change.

Inter-generational relationships matter (Bessell, 2017).Adults can fail to see potential in every young person, especially those already disadvantaged. But if adults treat them differently, by supporting young people's participation in educational decisions through consistently high expectations and not judging, as well as the timely sharing of their insights, they become significant in enabling change. Young people in this study wanted adults to rethink how they envisaged their lives by spending time to get to know them and who they really were. Thus enabling them to share their own understandings of the world, and working with them to imagine potential futures and how to get there.

Expectations are important and have already been identified as good predictors of attainment (Goyette, 2008). However, standardisation and performance driven school processes can limit what adults 
understand about young people to prior academic attainment, thereby ignoring their hopes, dreams and other talents. The movie designs demonstrated these tensions as experienced by young people. Yet, they were able to envisage how adults could be important in journeying with them towards their hopes and dreams. Through positive inter-generational relationships, they also recognised that their own personal qualities were important - their interests and talents as well as their perseverance and effort.

Whitty et al., (2015) argues that rights-based responses cannot address inequalities in education, because disadvantaged young people do not possess the capacities to exercise these rights, but this overlooks adults' actions in constituting barriers through inter-generational relationships and the control of resources. The arts-based participatory approaches, instead of positioning young people as lacking capacities, started from their perspectives and demonstrated how it is possible to bring together young people, when they share an interest in an issue to identify and co-create opportunities for change (Gair \& Moloney, 20I3). The relationships they constituted were effective in imagining 'roadmaps' for the future (Oyserman, Destin \& Novin, 2004) and bringing hope within challenging political contexts (Boliver, Gorard \& Siddiqui, 20।7).

The study was limited by small participant numbers. Global forces affecting priorities and relationships in schools, also provoke questions as to whether rightsbased responses can ever be possible or even desirable in UK education systems. Yet, opportunities in these systems that value young people's perspectives and well-being are integral to education that promotes human flourishing (Spratt, 2016). By adopting participatory methods that encourage young people to imagine, not only their future selves, but how barriers and enablers influence their journeys, they may be able to identify and lead the way for change. The challenge now is to translate this into meaningful educational experiences that can be facilitated within the educational system.

\section{References}

Aldridge, J. (2017). Advancing participatory research. Relational Social Work, I (2), 26-35.

Archer, L. (2007). Diversity, equality and higher education:A critical reflection on the ab/uses of equity discourse within widening participation. Teaching in Higher Education, I2(5-6), 635-653. https://doi. org/10.1080/13562510701595325

Archer, L., DeWitt, J., \& Wong, B. (20I4). Spheres of influence: what shapes young people's aspirations at age 12/13 and what are the implications for education policy? Journal of Education Policy, 29(I), 58-85. https:// doi.org/ I0.1080/02680939.2013.790079

Bassot, B., Barnes, A., \& Chant, A. (20I4). A Practical Guide to Career Learning and Development: Innovation in careers. Abingdon: Routledge.

Bessell, S. (2017). The role of inter-generational relationships in children's experiences of community. Children and Society, 3 I (4), 263-275. https://doi. org/I0.1 I II/chso. 12197

Boliver V., Gorard S., \& Siddiqui N. (20I7). How can we widen participation in higher education? The promise of contextualised admissions. In R. Deem and H. Eggins (Eds.), The University as a critical institution? Rotterdam: SensePublishers.

Clandinin, D.J., \& Huber J. (2002). Narrative inquiry: toward understanding life's artistry. Curriculum Inquiry, 32(2), I6 I-169. https://doi.org/ I0. I I I I/ |467$873 \times .00220$

CRC (Committee on the Rights of the Child) (2008). Forty-ninth session consideration of reports submitted by states parties under Article 44 of the convention, concluding observations: United Kingdom of Great Britain and Northern Ireland. Geneva: UN OHCHR Committee on the Rights of the Child.

Destin, M., \& Oyserman, D. (2009). From assets to school outcomes: how finances shape children's perceived possibilities and intentions. Psychological Science, 20, 4 I4-4 I8. https://doi.org/ I 0.I I I I/j. I4679280.2009.02309.x

Erikson, M.G. (2007). The meaning of the future: toward a more specific definition of possible selves. 
Review of General Psychology, I I (4), 348-35. https://doi. org//0.1037//089-2680.1 I.4.348

Gair, S., \& Moloney, S. (20I3). Unspeakable stories: when counter narratives are deemed unacceptable. Qualitative Research Journal, I3(I), 49-6I. https://doi.

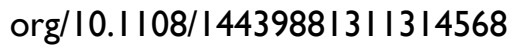

Garrett, P.M. (20I6). Questioning tales of 'ordinary magic':'resilience' and neoliberal reasoning. British Journal of Social Work, 46 (7), 1909-1925. https://doi. org/10.1093/bjsw/bcv017

Goyette, K.A. (2008). College for some to college for all: Social background, occupational expectations, and educational expectations over time. Social Science Research, 37(2), 46 I-484. https://doi.org//0.1016/j. ssresearch.2008.02.002

Grant, T. (2017). The complexity of aspiration: the role of hope and habitus in shaping working-class young people's aspirations to higher education. Children's Geographies, 15 (3), 289-303. https://doi.org// 0.1080//4 733285.2016 .1221057

Harrison, N. (2018). Using the lens of 'possible selves' to explore access to higher education: a new conceptual model for practice, policy, and research. Social Science, 7, 209. https://doi.org// 0.3390/ socsci7100209

Hayward, G., \& Williams, R. (20II). Joining the big society: am I bothered? London Review of Education, 9(2), 175-189. https://doi.org/I0.1080/I4748460.20II.585877

Hinyard, L. J., \& Kreuter, M.W. (2007). Using narrative communication as a tool for health behavior change: a conceptual, theoretical, and empirical overview. Health, Education and Behaviour, 34(5), 777-792. https://doi. org// $0.1177 / 1090198106291963$

Hutchinson, J., Bonetti, S., Crenna-Jennings, W., \& Akhal, A. (2019) Education in England:Annual report 2019. London: Fair Education Alliance and Education Policy Institute.

McNamara, P., Harvey, A., \& Andrewartha, L. (2017). Passports out of poverty: Raising access to higher education for care leavers in Australia. Children and Youth Services Review, 97, 85-93. https://doi. org/10.1016/j.childyouth.2017.07.015

Oyserman, D., Destin, M., \& Novin, S. (2015). The context-sensitive future self: possible selves motivate in context, not otherwise. Self and Identity, 14, 173-88. https://doi.org//0.1080/15298868.2014.965733

Pimlott-Wilson, H. (20I I). The role of familial habitus in shaping children's views of their future employment. Children's Geographies, 9(I), I I I-I I8. https://doi.org/I0. I080/I4733285.20I I.540443

Prout, A. \& James, A. (2015). A new paradigm for the sociology of childhood?: provenance, promise and problems. In A. James \& A. Prout (Eds.), Constructing and reconstructing childhood: Contemporary issues in the sociological study of childhood (Classic edition) (pp. 6-28). Abingdon: Routledge.

Sanders, J., Munford, R., \& Thimasarn-Anwar,T. (20I6). Staying on-track despite the odds: factors that assist young people facing adversity to continue with their education. British Education Research Journal, 42(I), 5673. https://doi.org// 0.1002/berj.3202

Satchwell, C., Larkins, C., Davidge, G., \& Carter, B. (2020). Stories as findings in collaborative research: making meaning through fictional writing with disadvantaged young people. Qualitative Research, 2020, I-I8. https://doi.org/| 0. I |77/| 468794| 20904892

Shaw, J. (2012). A case study exploring student choice making behaviour and progression agreements. Research in Post-Compulsory Education, 17(1), I I5- 123. https://doi.org/I0.1080/I3596748.20I2.649969

Skånfors, L. (2009). Ethics in child research: children's agency and researchers' 'ethical radar'. Childhoods Today, $3(I), I-22$.

Spratt, J. (2016). Childhood wellbeing:What role for education? British Educational Research Journal, 42(2), 223-239. https://doi.org//0.1002/berj.32II

St Clair, R., \& Benjamin,A. (20I I). Performing desires: the dilemma of aspirations and educational attainment. British Educational Research Journal, 37(3), 50 I-517. https://doi.org/I0.1080/01411926.2010.481358 
Spohrer, K. (2016). Negotiating and contesting 'success': Discourses of aspiration in a UK secondary school. Discourse, 37(3), 4I I-425. https://doi.org/10.1080/0I596 306.2015 .1044423

Strahan, E. J., \& Wilson, A. E. (2006). In C. Dunkel, \& J. Kerpelman (Eds), Possible Selves:Theory, Research and Applications (pp. I-15). New York: Nova Science Publications Inc.

Wainwright, L., Nee, C., \& Vrij,A. (20I8). 'I don't know how, but l'll figure it out somehow': future possible selves and aspirations in 'at-risk' early adolescents. International Journal of Offender Therapy and Comparative Criminology, 62(2), 504-523. https://doi. org/ $/ 0.1177 / 0306624 X 16665182$

Whitty, G., Hayton, A., \& Tang, S. (2015).Who you know, what you know and knowing the ropes: a review of evidence about access to higher education institutions in England. Review of Education, 3(I), 27-67. https://doi. org/I0.1002/rev3.3038

Wrigley, T. (2015). Gove's curriculum and the GERM. FORUM for Promoting 3-19 Comprehensive Education, 57(2), 197-204. http://doi.org// 0.15730/ forum.2015.57.2.197

\section{For correspondence}

Dr Deborah Crook,

University of Central Lancashire

Dcrook5@uclan.ac.uk 